\title{
Giant Rats for Meat-and some Taboos
}

\author{
S. S. Ajayi
}

Meat is short in southern Nigeria. Wild animal meat is popular, but the wildlife is seriously depleted. To help supply the demand for meat and also ease the pressure on the wildife, a quick-breeding species, the giant or pouched rat, is being domesticated. The author describes some of the widely held taboos about this meat, which nevertheless is in considerable demand.

In southern Nigeria a fifth of the animal protein eaten by rural people comes from wild animals, even though the wildlife is seriously depleted. The demand for meat has greatly increased due to the rapid population growth, and the present domestic animals cannot produce enough.

One way to increase protein production is by domesticating fastbreeding wild animals that are socially acceptable as a source of meat. One possibility is the African giant rat, or pouched rat, Cricetomys gambianus, now being domesticated at the Forestry Department of Ibadan University. A nocturnal burrowing rodent, this rat weighs up to $1.5 \mathrm{~kg}$, and may produce six litters of $1-5$ young a year. The gestation period is about 28 days and young rats are weaned at about 26 days. Sex ratio from birth records is about 1 male: 2 females, which could be advantageous in a domestic animal.

To find out whether meat from this rat would be acceptable questionnaires were sent out to towns and villages where important ethnic groups were represented. Of the 52 per cent returned, 56 per cent accepted the giant rat as a source of meat. Questionnaires were also used to find out the main reasons for rejecting this meat, and revealed a number of taboos.

\section{A Supernatural Creature}

In the Western State, most people in the Oyo division believe that the giant rat is used in making witchcraft to torment people or to utter an evil wish against an enemy. Some also believe that it is a supernatural creature, capable of changing to a human being, and going to the market to buy food and household goods, which is why few giant rats are caught in their burrows on market days; the bits of broken pots, cowries and various foodstuffs usually to be found in the burrows are 'remains of the rat's purchases in the markets'. In Ife, Ondo, and Igbara Odo areas, as well as the witchcraft taboo, people believe that the rats eat human corpses, which is why they are common in cemeteries. In Ondo division people have specially strong feelings against eating the giant rats because, they say, during some inter-tribal wars before Nigeria was colonised by the British, the giant rats offered their ancestors special supernatural help in fighting their enemies, and they do not believe in killing and eating 
their 'military allies'. This regard for the rat as a sacred animal would have resulted in it becoming a pest to food crops if it had not been hunted by other people living there who had moved in from other parts of the State. In Ekiti some people believe that the rats eat human corpses, and also that the child of a pregnant woman who ate the rat would become a rogue and an outcast.

In Ishan, Auchi and Benin divisions of the Mid-western state, dislike of the giant rat was attributed to its presence in cemeteries, and because it was a sacrificial animal. A man who touched the white tip of the tail would become impotent.

The Ibos in the East Central State believe that dead people change to giant rats, carrying on their normal trades at night; hence common items found in the markets are also found in their burrows. The Ibibios in the Rivers and South Eastern States have similar beliefs.

In Kabba division of Kwara State, the Yagba, Owe and Ijunmu people believe that the giant rats are clever at escaping predators (including human beings) because to find out what the future holds for them they consult their oracles. These are the pods of the oil bean tree Pentaclethra marophylla and pericarps of kernels of the oil palm Elaeis guineensis which are always found in the burrows.

Nevertheless, despite all these taboos, giant rat meat is in high demand, especially in urban areas in the south. In Ibadan city it is difficult to come by a smoked rat at all. The market price varies from about $\mathrm{N} 1$ for a medium-sized smoked rat to $\mathrm{N} 1.50 \mathrm{~K}$ for a large one. (1 Naira=US\$1.55=£0.58p). At its meeting in February 1973, the National Wildlife Conservation Committee (the national body dealing with wildlife administration in which the forestry services of the twelve Nigerian states are represented) agreed that giant rat tastes better than most other meat and its domestication should be encouraged.

In a heterogeneous society such as Nigeria it is difficult to select a wildlife species for domestication which has not got some taboos associated with it. The taboos originated at a time when wildlife was abundant and people could afford to be selective about what they ate. In East Africa where wildlife is still relatively abundant, some tribes still believe that leprosy results from eating zebra, and some tribes prohibit the eating of eland and elephant. Chickens are still not eaten in some parts of West Africa today. However, since in Nigeria the giant rats have a wide social acceptance, domestication might persuade more people to eat the meat, especially if rearing methods are hygienic.

The result is that the Federal Departments of Forestry and Forest Research and the University of Ibadan have made generous contributions to a domestication programme. Captive giant rats have bred successfully, and it has been established that they can be raised with a small capital outlay-about N0.30 per animal from weaning age to adult size. It is also intended that another rodent, the cane rat or grass cutter Thryonomys swinderianus should be domesticated, and that, to minimise costs, this should be done under semi-natural conditions. 